\title{
Pattern of malformations in central nervous system and its association with other congenital anomalies in perinates
}

\author{
Hari Charan Sarangsa ${ }^{1}$, Jayanta Kumar Sarkar ${ }^{2, *}$, Giriraj Kusre ${ }^{3}$, Krishna Kanta Biswas ${ }^{4}$ \\ ${ }^{1}$ Assistant Professor, ${ }^{2}$ Associate Professor, ${ }^{4}$ Demonstrator, Dept. of Anatomy, Silchar Medical College, Assam, \\ ${ }^{3}$ Associate Professor, Dept. of Anatomy, Assam Medical College, Dibrugarh, Assam, India \\ *Corresponding Author: \\ Email: jksarkar31@gmail.com
}

Received: $13^{\text {th }}$ May, 2018

Accepted: $15^{\text {th }}$ June, 2018

\begin{abstract}
Introduction: The congenital malformations of the central nervous system is one of the leading causes of perinatal mortality in this region of the country. It may present as an isolated defect or may be associated with other organ system malformations.

Aims and Objectives: Aim of the present study was to find out the pattern of congenital malformations in the central nervous system both in live and still born perinates. Our main objective was to ascertain its association with other organ systems most commonly involved.

Materials and Methods: The prospective study was carried out on 76 perinates having congenital anomalies out of 15,970 births $(15,614$ live born and 356 stillborn) ranging from 28th weeks of gestation to 7 days after birth. Twenty, out of 76 were born with central nervous system malformations.

Results and Observations: The congenital malformations of central nervous system were found to be $26.31 \%$. Anencephaly was the most common malformation (50\%) observed amongst the central nervous system in the study with a female preponderance 1.5: , followed by spina bifida with meningomyelocele (35\%), hydrocephalus (10\%) and holoprosencephaly (5\%). Anencephaly was associated with occipital meningoencephalocele in $10 \%$ cases.

Conclusion: Anencephaly is the most common malformations in the study, followed by spina bifida and meningomyelocele. The other malformations found in the central nervous system are hydrocephalus, meningoencephalocele and holoprosencephaly. The incidence of congenital malformations in present study is comparatively lower than in other parts of India and abroad.
\end{abstract}

Keywords: Congenital malformation, Perinates, Anencephaly, Spina bifida, Meningomyelocele.

\section{Introduction}

The malformations of the central nervous system result from alterations in the morphogenesis or histogenesis of the nervous tissue itself. Some of the aberrations, however are extrinsic in that they result from developmental failure or abnormalities in the mesodermal structure related to the early nervous system. Proper differentiation of these mesodermal derivatives such as notochord, somite, vertebrae and mesenchyme are essential for normal development of the brain and spinal cord. ${ }^{1}$ Congenital anomalies of the central nervous system are major causes of mortality during perinatal period and results from failure of the closure of the neural tube between third and fourth week of embryonic life. Major neural tube defects are spina bifida, meningocele, meningomyelocele, anencephaly and meningoencephalocele., ${ }^{2,3}$ Anencephaly occurs if the rostral part of neural tube fails to close, associated with degeneration of the exposed neural plate tissue ${ }^{1}$ resulting in failure to develop major parts of the brain. In place of the normal neural tissue, there are thin-walled vascular channels resembling the choroid plexus and masses of neural tissue. ${ }^{4}$ Anencephaly is the most severe form of neural tube defect and is not compatible with life. Most of these cases are diagnosed during pregnancy by ultrasonography or amniocentesis and after delivery of the babies in neonates. ${ }^{5}$ Anencephalic infants are mostly stillborn or die shortly after birth. Spina bifida is midline defect of vertebral arches without protrusion of the spinal cord or meninges. The most common site of spina bifida is in the lumbosacral region. Meningocele occurs when the meninges protrude through the defect in the posterior arches of vertebrae. Spina bifida with meningomyelocele is a more common and severe defect than spina bifida with meningocele. Hydrocephalus results from blockage of cerebrospinal fluid in the ventricular system or subarachnoid space. Meningoencephalocele results from defective closure of the rostral neuropore during the fourth week and affects skull with protrusion of meninges and cerebellum, cerebrum or portions of the brainstem. ${ }^{6}$

\section{Aims and Objectives}

Aim of the present study was to find out the frequency of the pattern of major congenital malformations in central nervous system both in live and still born perinates. Our objective was to ascertain its association with anomalies of other organ systems most commonly involved.

\section{Materials and Methods}

The prospective study was carried out on 76 perinates having congenital anomalies out of 15970 births (8,288 male and 7,682 female) in the Department of Anatomy, Assam Medical College \& Hospital, Dibrugarh. The specimens $(15,614$ live born \& 356 
stillborn babies) were procured from the Department of Obstetrics \& Gynaecology, Assam Medical College \& Hospital, Dibrugarh. Twenty, out of 76 were born with central nervous system malformations.

Study Population: Live and still born perinates ranging from $28^{\text {th }}$ weeks of gestation to 7 days after birth. Foetuses born before 28 weeks of gestation, terminated pregnancy and macerated babies were excluded from the present study.

The still born foetuses were examined in the Department of Anatomy after fulfillment of all official procedures to detect presence of congenital malformations and the expert opinion was sought for confirming diagnosis. When malformation was detected, information regarding birth order, sex, birth weight were obtained by systematic maternal and paternal interviews, and the information were noted in a pretested structured proforma. The written consent from the parents was taken before examination and dissection of perinates. The result and observations were presented in tabular form and in figure. Statistical calculations were done in percentage and in per thousand live birth.

\section{Results and Observations}

In the present study, total 76 (62 stillbirth, 17.41\% \& 14 live birth, $0.09 \%$ ) cases of congenital malformations were found in 15,970 births (Table 1). Total percentage of congenital malformation was found to be $0.47 \%$. Out of 76 congenital malformations, 20 cases $(26.31 \%)$ were found to be of central nervous system with male female ratio 1.5:1 (Table 1).

Anencephaly was the most common (50\%) malformation observed in the central nervous system with male female ratio $1: 1.5$ (table 2 , chart 1 , Fig. $1 \&$ $5)$. Incidence of anencephaly was 0.62 per 1000 birth. Spina bifida with meningomyelocele was observed in $35 \%$ cases of central nervous system malformation with an incidence rate of 0.438 per 1000 birth (table 2, chart 1 \& Fig. 2). Hydrocephalus was noted in $10 \%$ cases with an incidence of 0.125 per 1000 birth (Table 2, Chart $1 \&$ Fig. 3). Holoprosencephaly was recorded in 5\% cases with an incidence of 0.063 per 1000 birth (Table 2).

Association with other organ system:

In the present study of central nervous system malformations, anencephaly showed association with occipital meningoencephalocele (10\%) (Table 2, Chart 2, Fig. 1\& 5), craniorachischisis (5\%) (Fig. 4), spina bifida (20\%), with CTEV and syndactyly (10\%) and with omphalocele major, single umbilical artery and contracture right wrist (5\%) (Table $2 \&$ Chart 2). Spina bifida and meningomyelocele showed association with CTEV and polydactyly 10\%) and omphalocele major, $\mathrm{CDH}$, imperforate anus (5\%) cases (table $2 \&$ chart 2 ). Hydrocephalus showed association with syndactyly, CTEV (10\%), spina bifida and low set ear (5\%) (Table 2 \& Chart 2, Fig. 3). $5 \%$ cases of CNS malformations showed association of holoprosencephaly with cleft lip, cleft palate, proboscis, syndactyly and amputated digit. (Table 2 \& Chart 2)

Table 1: Showing frequency distribution of congenital malformations. $(n=76)$

\begin{tabular}{|c|c|c|c|c|c|c|c|c|}
\hline & Still & Live & Total & \multicolumn{5}{|c|}{ Central nervous system malformation $(n=20)$} \\
\hline No of cases & 356 & 15614 & 15970 & Male & Female & Total & $\begin{array}{c}\text { Male Female } \\
\text { ratio }\end{array}$ & $\begin{array}{c}\text { Incidence per } \\
1000 \text { births }\end{array}$ \\
\hline $\begin{array}{l}\text { Congenital } \\
\text { malformations }\end{array}$ & 62 & 14 & 76 & 12 & 08 & 20 & \multirow{2}{*}{$1.5: 1$} & \multirow[t]{2}{*}{1.25} \\
\hline Percentage $\%$ & $17.41 \%$ & $0.09 \%$ & $0.47 \%$ & $15.79 \%$ & $10.52 \%$ & $26.31 \%$ & & \\
\hline
\end{tabular}

Table 2: Frequency distribution of malformation in CNS \& its association with other organ system (n=20)

\begin{tabular}{|c|c|c|c|c|c|c|}
\hline \multicolumn{4}{|c|}{ Malformations in central nervous system } & \multicolumn{3}{|c|}{ Association with other organ system } \\
\hline Malformations & $\begin{array}{l}\text { No. of } \\
\text { cases }\end{array}$ & $(\%)$ & $\begin{array}{l}\text { Incidence per } \\
1000 \text { birth }\end{array}$ & Malformations & $\begin{array}{l}\text { Perce } \\
\text { ntage }\end{array}$ & $\begin{array}{l}\text { Incidence } \\
\text { per } 1000 \\
\text { birth }\end{array}$ \\
\hline \multirow{5}{*}{ Anencephaly } & \multirow{5}{*}{10} & \multirow{5}{*}{$50 \%$} & \multirow{5}{*}{0.62} & $\begin{array}{c}\text { Occipital } \\
\text { meningoencephalocele }\end{array}$ & $10 \%$ & 0.125 \\
\hline & & & & Spina bifida, & $20 \%$ & 0.250 \\
\hline & & & & Craniorachischisis & $5 \%$ & 0.063 \\
\hline & & & & CTEV, syndactyly & $10 \%$ & 0.125 \\
\hline & & & & $\begin{array}{l}\text { Omphalocele major, } \\
\text { Single umbilical artery, } \\
\text { Contracture right wrist }\end{array}$ & $5 \%$ & 0.063 \\
\hline \multirow{2}{*}{$\begin{array}{l}\text { Spina bifida \& } \\
\text { meningo-myelocele }\end{array}$} & \multirow[b]{2}{*}{07} & \multirow[b]{2}{*}{$35 \%$} & \multirow[b]{2}{*}{0.438} & CTEV, polydactyly & $10 \%$ & 0.125 \\
\hline & & & & $\begin{array}{l}\text { Omphalocele major, } \\
\mathrm{CDH}, \text { imperforate anus }\end{array}$ & $5 \%$ & 0.063 \\
\hline
\end{tabular}




\begin{tabular}{|l|c|c|c|c|c|c|}
\hline \multirow{2}{*}{ Hydrocephalus } & \multirow{2}{*}{02} & $10 \%$ & \multirow{2}{*}{0.125} & Spina bifida & $5 \%$ & 0.063 \\
\cline { 5 - 6 } & & & Low set ear & $5 \%$ & 0.063 \\
\hline Holoprosencephaly & 01 & $5 \%$ & 0.063 & $\begin{array}{c}\text { CTEV, syndactyly } \\
\text { proboscis, syndactyly \& } \\
\text { amputated digit }\end{array}$ & $5 \%$ & 0.063 \\
\hline
\end{tabular}

Table 3: Comparative data showing incidence of neural tube defects by various researchers

\begin{tabular}{|c|c|c|c|c|c|c|}
\hline Study group & Year & Anencephaly & Spina bifida & $\begin{array}{l}\text { Meningo- } \\
\text { myelocele }\end{array}$ & $\begin{array}{c}\text { Hydro- } \\
\text { cephalus }\end{array}$ & $\begin{array}{l}\text { Holoprose } \\
\text { n-cephaly }\end{array}$ \\
\hline Laurence et al & 1968 & $3.54 / 1000$ & $4.13 / 1000$ & - & $0.45 / 1000$ & - \\
\hline Tibrewala \& Pai & 1974 & $0.49 / 1000$ & $0.65 / 1000$ & - & $0.16 / 1000$ & - \\
\hline Mathur et al & 1975 & $3.8 / 1000$ & $0.3 / 1000$ & $0.9 / 1000$ & $1.9 / 1000$ & - \\
\hline Choudhury et al & 1984 & $0.52 / 1000$ & - & $0.24 / 1000$ & $0.43 / 1000$ & - \\
\hline Swain et al & 1994 & $1.52 / 1000$ & - & $0.76 / 1000$ & $2.03 / 1000$ & - \\
\hline Rajab et al & 1998 & $0.69 / 1000$ & & $0.45 / 1000$ & $0.44 / 1000$ & \\
\hline Hendricks et al & 1999 & $4.9 / 10,000$ & $6.7 / 10,000$ & - & - & - \\
\hline Datta \& Chaturvedi & 2000 & $0.69 / 1000$ & - & $0.34 / 1000$ & $0.34 / 1000$ & - \\
\hline $\mathrm{CDC}$ & 2000 & $6.1 / 10000$ & $6.3 / 10000$ & - & - & - \\
\hline Fida et al & 2007 & - & - & $0.37 / 1000$ & $0.74 / 1000$ & - \\
\hline Snell R S & 2010 & $6 / 1000$ & $6 / 1000$ & - & $6 / 1000$ & - \\
\hline Golalipour et al & 2010 & $11.4 / 10,000$ & $12.7 / 10,000$ & - & - & - \\
\hline Sunethri et al & 2011 & $50 \%$ & $41.66 \%$ & $8.33 \%$ & - & - \\
\hline Saiyad \& Jadav & 2012 & $(41.38 \%)$ & $(10.34 \%)$ & $(10.34 \%)$ & $(13.80 \%)$ & - \\
\hline Pujari \& Pujari & 2012 & - & $0.23 / 1000$ & $1.64 / 1000$ & $0.47 / 1000$ & - \\
\hline Sadler TW & 2015 & $1 / 500-1000$ & $1 / 1000$ & $1 / 1000$ & $1 / 1200$ & $1 / 15,000$ \\
\hline Moore K L & 2016 & $1 / 1000$ & - & $1 / 2000$ & - & - \\
\hline Bhide \& Kar & 2018 & $17.1 / 10,000$ & $8.45 / 10,000$ & - & - & - \\
\hline \multicolumn{2}{|l|}{ Present study } & $\begin{array}{l}10(50 \%) \\
0.62 / 1000 \\
\text { Births }\end{array}$ & \multicolumn{2}{|c|}{$\begin{array}{c}7(35 \%) \\
0.438 / 1000 \text { Births }\end{array}$} & $\begin{array}{l}2(10 \%) \\
0.125 / 10 \\
00 \text { Birth }\end{array}$ & $\begin{array}{c}1(5 \%) \\
0.063 / 1000 \\
\text { Births }\end{array}$ \\
\hline
\end{tabular}

Chart 1: Frequency distribution of malformations in central nervous system

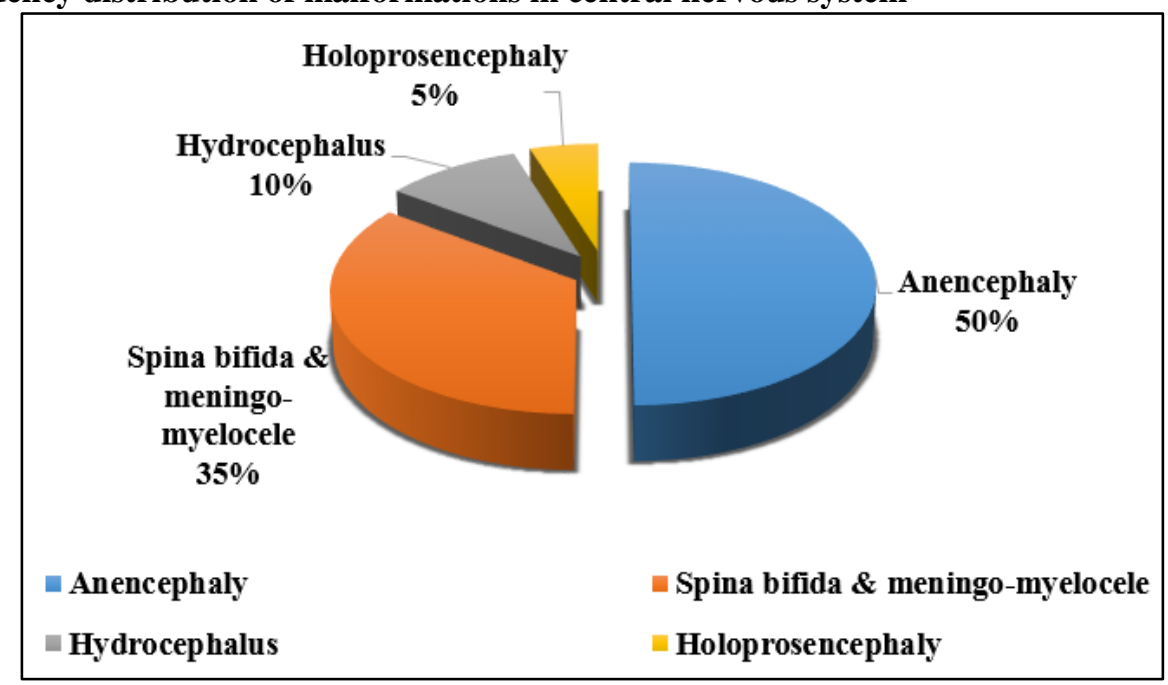


Chart 2: Association of CNS malformation with other organ system

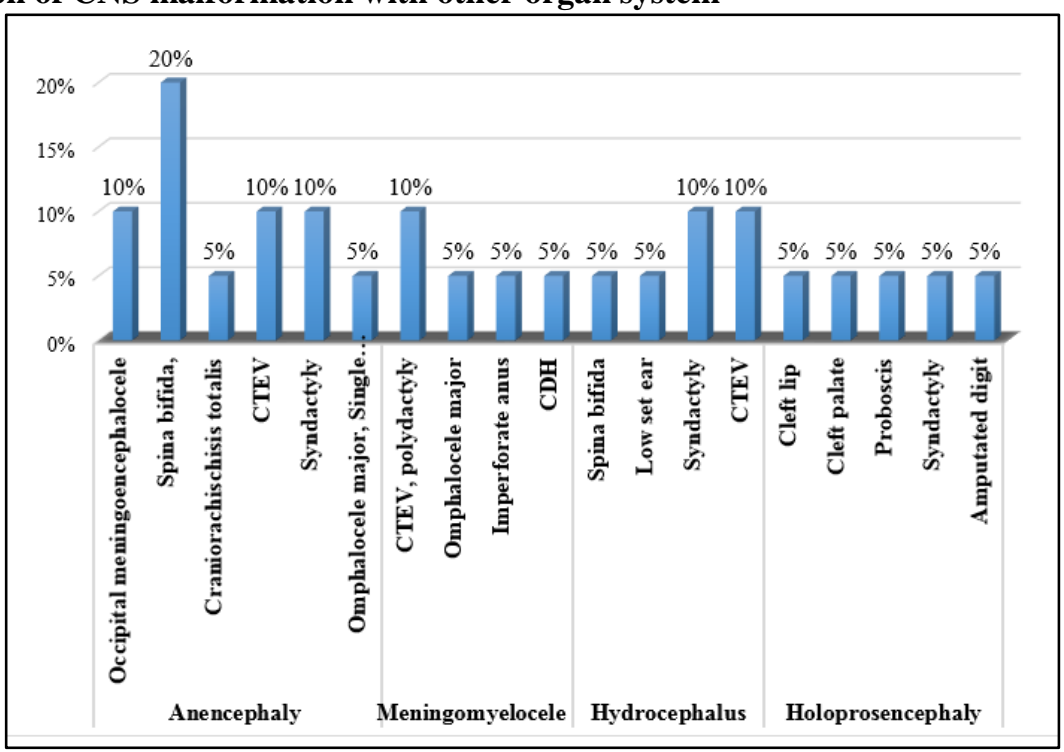

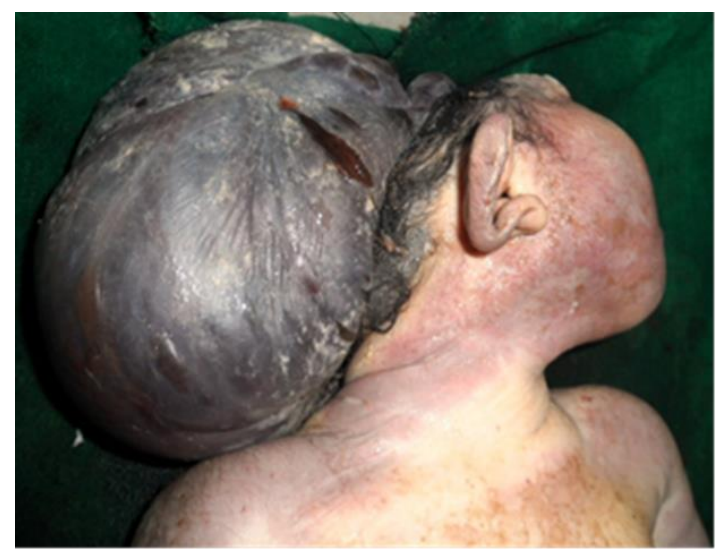

Fig. 1: Anencephaly with occipital meningoencephalocele

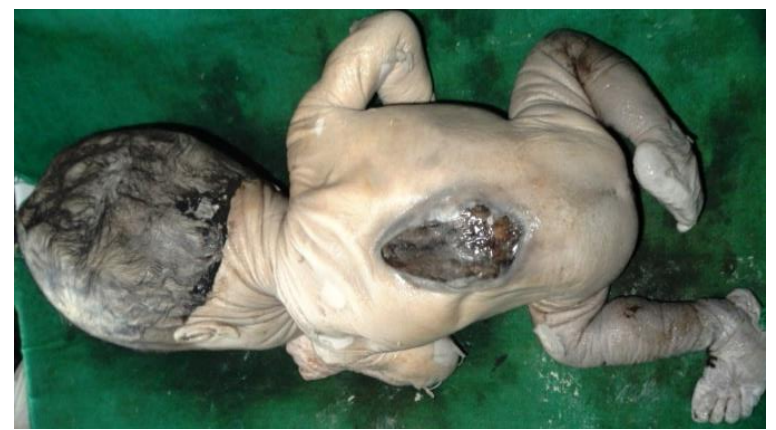

Fig. 2: Spinabifida and meningomyelocele with CTEV

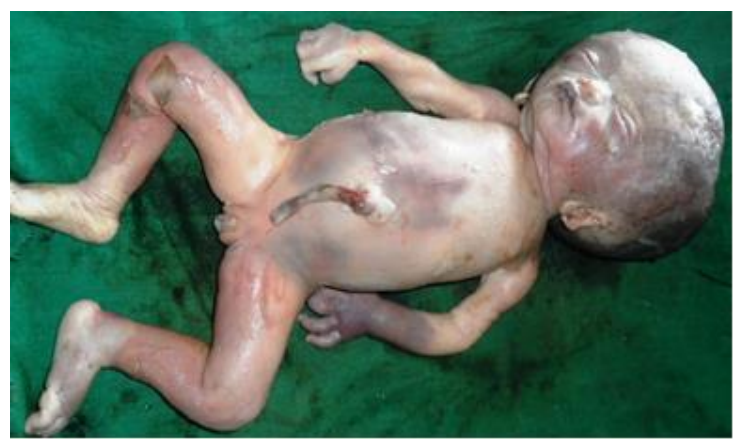

Fig. 3: Hydrocephalus with low set ear, CTEV \& syndactyly

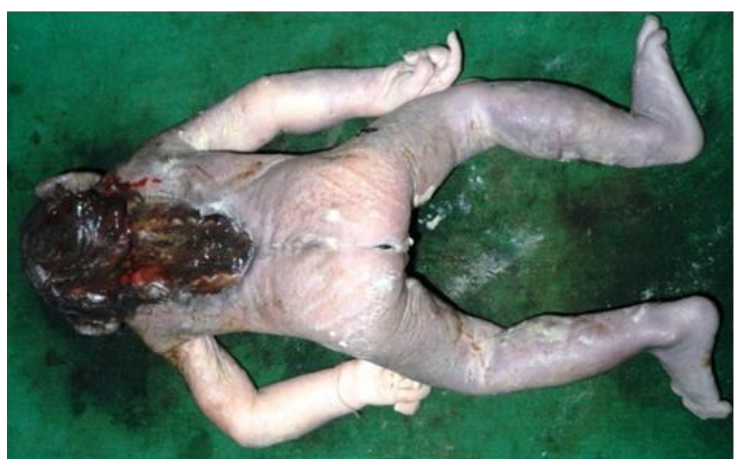

Fig. 4: Craniorachischisis totalis 


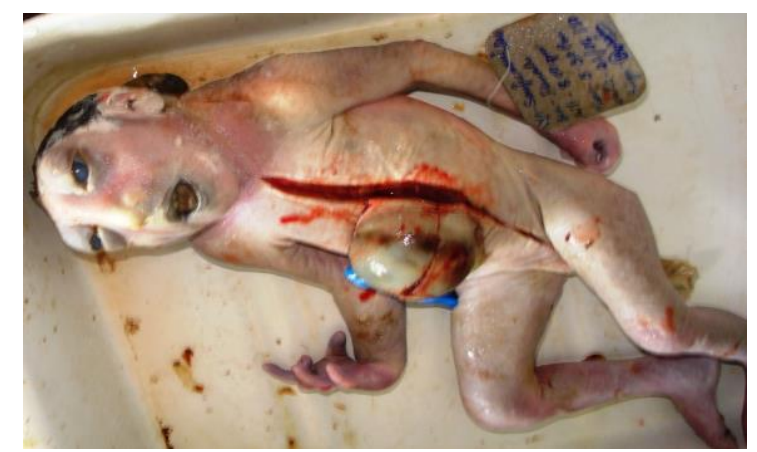

Fig. 5: Anencephaly with occipital meningoencephalocele (cerebellum), omphalocele major, single umbilical artery and contracture right wrist

\section{Discussion}

The present study revealed $26.31 \%$ cases of congenital malformation in the central nervous system with an incidence of 1.25 per 1000 birth in comparison to Siddesh et $\mathrm{al}^{7} 31.6 \%$, Singh $\mathrm{A}^{8} 20.5 \%$, Singh \& Sinha $^{31} 12.8 \%$, Fida et $\mathrm{al}^{9} 1.9 / 1000$, Rajab et $\mathrm{al}^{10}$ $1.25 / 1000$ birth, Golalipour et $\mathrm{al}^{11} 25.4 / 10,000$ and Bhide \& $\operatorname{Kar}^{12} 28.93$ per 10,000 live births (Table 3). According to Schoenwolf $\mathrm{G} \mathrm{C},{ }^{13}$ open neural tube defects occur in about $0.1 \%$ of all live births and the frequency of it as a whole in the United States is approximately $0.1 \%$. Anencephaly was the most common (50\%) congenital malformations among central nervous system in the present study. It was comparable with the study of Sunethri et $\mathrm{al}^{14}(50 \%)$, Moradi et a ${ }^{15}$ (50\%), Kulkarni et $\mathrm{al}^{16}(45 \%)$ and Saiyad \& Jadav ${ }^{17}$ $(41.38 \%)$. According to Parthasaraty $\mathrm{A}^{18}$ incidence of anencephaly was observed 1 in 1000 births. In the present study incidence of anencephaly was $0.62 / 1000$ live birth in comparison to Rajab et al ${ }^{10} 0.69 / 1000$, Datta \& Chaturvedi ${ }^{19} 0.69 / 1000$, Tibrewala \& $\mathrm{Pai}^{20} \quad 0.49 / 1000$ and Choudhury et $\mathrm{al}^{21} 0.52 / 1000$. Anencephaly was recorded by Mathur et al ${ }^{22} 3.8 / 1000$, Swain et $\mathrm{al}^{23} 1.52 / 1000$, Hendrik et al, ${ }^{24} \mathrm{CDC},{ }^{25}$ Golalipour et $\mathrm{al}^{11}$ and Bhide \& $\mathrm{Kar}^{12}$ as 4.9, 11.4, 6.1 and 17.1 per 10,000 live birth respectively (table 3 ). Sadler T $\mathrm{W}^{5}$ stated that anencephaly occurs in 1 per 5,000 births and is more common in females than in males. According to Moore $\mathrm{K} \mathrm{L},{ }^{26}$ anencephaly occurring at least once in every 1000 births and two to four times more common in females than in males. In the present study, the female preponderance was seen with ratio of 1.5:1. Spina-bifida with meningomyelocele was the second most common malformations of the central nervous system (35\%) in the present study. The incidence is quite low when compared to Sunethri et al ${ }^{12}$ (41.66\%) and high compared to the observations of Saiyad \& $\operatorname{Jadav}^{17}(10.34 \%)$. On the contrary, the present study was comparable to the observations of Mathur et $\mathrm{al}^{22} \quad 0.3 / 1000$, Datta \& Chaturvedi ${ }^{19} \quad 0.34 / 1000$ and Catibusic F H et $\mathrm{al}^{2}$ 1/4000 live births. Spina bifida was found by Hendricks et al, ${ }^{24} \mathrm{CDC},{ }^{25}$ Golalipour et a ${ }^{11}$ and Bhide \& $\mathrm{Kar}^{12}$ as $6.7,6.3,12.7$ and 8.45 per 10, 000 live birth respectively which was higher in comparison to the present study of $0.438 / 1000$ live birth. Hydrocephalus was noted in $10 \%$ cases which was comparable with Pinar et $\mathrm{al}^{27} 12.4 \%$. The incidence is quite low $0.125 / 1000$ when compared with Rajab et $\mathrm{al}^{9}$ $0.44 / 1000$, Laurence et $\mathrm{al}^{28} 0.45 / 1000$, Pujari \& Pujari ${ }^{29} 0.47 / 1000$ and Snell RS $^{4}$ 6/1000. Hydrocephalus develops in at least $80 \%$ of patients with meningomyelocele by Catibusic $\mathrm{F} \mathrm{H}$ et $\mathrm{al}^{2}$ or may be associated with spina bifida and meningocele by Snell $\mathrm{R}$ $\mathrm{S} .{ }^{4}$ In the present study hydrocephalus was observed in still born male full-term fetus associated with spina bifida and CTEV (Fig. 2). Meningoencephalocele occurs approximately once in every 2000 births by Moore $\mathrm{K} \mathrm{L}^{6}$ and $11.6 \%$ by Mahadevan and Bhat. ${ }^{30}$ In the present study occipital meningoencephalocele along with anencephaly was noted in $10 \%$ cases with incidence of 0.125 per 1000 birth (Table 2, Chart 2) in comparison to Rajab et $\mathrm{al}^{9} 0.45 / 1000$ (table 3 ). Holoprosencephaly observed 1/ 15,614 live birth in comparison to Sadler T $\mathrm{W}^{5} 1 / 15,000$ live births.

From the present study it had been found that congenital malformation of the central nervous system was one of the leading causes of perinatal mortality in this region of the country. It may present as an isolated defect or may be associated with other organ system malformations.

\section{Conclusion}

The present study reveals the pattern and frequency of malformation in the central nervous system and its association with other organ system commonly involved. Anencephaly is the most common malformations followed by spina bifida and meningomyelocele. The other CNS malformations are hydrocephalus, meningoencephalocele and holoprosencephaly. The incidence of congenital malformations in present study is comparatively lower than in other parts of India and abroad. The incidence of congenital anomalies is declining significantly following folic acid administration. The malformations resulting from neural tube defects, can be prevented by taking folic acid daily three months prior to conception and continuing throughout pregnancy.

\section{Conflict of Interest: None}

\section{Reference}

1. Hamilton W J, Mossman H W: Nervous system: in Hamilton, Boyd and Mossman's Human Embryology $4^{\text {th }}$ edition. 1972;487-88

2. Catibusic F H et al: Congenital malformations of the central nervous system: clinical approach: Bosnian Journal of Basic Medical Sciences. 2008;8(4):356-360.

3. Jones K L, Jones M C, Campo M D: Brain: Major anomalies: in Smith's recognizable patterns of human malformation, $7^{\text {th }}$ edition. $2013 ; 943-946$. 
4. Snell R S: The development of the nervous system: Clinical neuroanatomy, 7th edition. 2010;514-515.

5. Sadler T W: Third to eighth weeks, central nervous system: Langmans medical embryology. $13^{\text {th }}$ edition, 2015;71-80, 306-342.

6. Moore K L, Persaud T V N, Torchia M G: Nervous system: The Developing Human: Clinically oriented embryology, $10^{\text {th }}$ edition. 2016;379-417.

7. Siddesh A, Gupta G, Sharan R, Agarwal M, Phadke S R: Spectrum of prenatally detected central nervous system malformations neural tube defects continue to be the leading fetal malformation: Indian J Med Res. 2017;145:471-478.

8. Singh A, Gupta R K: Pattern of congenital anomalies in newborn: A Hospital based prospective study: $J K$ Science. 2009;11(1):34-36.

9. Fida N M, Al-Aama J, Nichols W: A prospective study of congenital malformations among live born neonates at a University Hospital in Western Saudi Arabia. Saudi Med J. 2007;2 (9):1367-1373.

10. Rajab A, Vaishnav A, Freeman N V, Patton M A: Neural tube defects and congenital hydrocephalus in the Sultanate of Oman: Journal of Tropical Pediatrics. 1998;44(5):300-303

11. Golalipour M J, Najafi L, Keshtkar A A: Neural tube defects in native Fars ethnicity in Northern Iran: Iranian $J$ Publ Health. 2010;39(3):116-123.

12. Bhide P, Kar A: A national estimate of the birth prevalence of congenital anomalies in India: systematic review and meta-analysis. BMC Pediatrics. 2018;18:175 https://doi.org/10.1186/s12887-018-1149-0

13. Schoenwolf G C, Bleyl S B, Brauer P R, Francis-West P H: Fourth week: Forming the embryo: Larsen's human embryology, 4th edition. 2009:107-117

14. Sunethri Padma, Ramakrishna D, Jijiya Bai P, Ramana P $V$ : Pattern of distribution of congenital anomalies in stillborn: A Hospital Based Prospective Study: International Journal of Pharma and Bio Sciences. 2011;2(2):604-610.

15. Moradi B, Katouli F S, Gity M, Kazemi M A, Shakiba M, Masrour F F: Neural tube defects distribution and associated anomalies diagnosed by prenatal ultrasonography in Iranian fetuses: J Obster Gynecol Cancer Res. J Obstet Gynecol Cancer Res. 2017;2(4):e64382. doi: 10.5812/jogcr.64382

16. Kulkarni M L, Mathew M A, Reddy V: The range of neural tube defects in Southern India: Archives of Disease in Childhood.1989;64:201-204.

17. Saiyad S S, Jadav H R: Study of congenital malformations in central nervous system and Gastrointestinal tract: National J of Med Research. 2012;2(2):121-123

18. Parthasarathy A: IAP Textbook of Pediatrics 2nd Ed. Jaypee Brothers, Medical Publishers (P) Ltd, New Delhi. 2003;291-295
19. Datta V, Chaturvedi P: Congenital malformations in rural Maharastra: Ind Pediatr. 2000;37(9):988-1001.

20. Tibrewala NS, Pai PM: Congenital malformations in the newborn period. Ind Pediatr. 1974;11(6):403-06.

21. Choudhury A, Talukder G, Sharma A: Neonatal congenital malformations in Calcutta. Indian Journal of Pediatrics. 1984;21:399-405.

22. Mathur BC, Karan S, Vijaya Devi K K. Congenital malformations in the newborn. Indian Pediatr. $1975 ; 12: 179-83$.

23. Swain S, Agrawal A, Bhatia BD: Congenital Malformations at birth. Indian Journal of Pediatrics. 1994;31;1187-1191.

24. Hendricks K A, Simpson J S, Larsen R D. Neural tube defects along the Texas-Mexico border, 1993-1995. Am J Epidemiol. 1999;149(12):1119-27.

25. CDC: Neural Tube Defect Surveillance and Folic Acid Intervention-Texas-Mexico Border, 19931998;2000;49(1):1-4. https://www.cdc.gov/mmwr/preview/mmwrhtml/mm4901 a1.htm

26. Moore K L, Persaud T V N, Torchia M G: Nervous system: Before we are born, Essentials of embryology and birth defects, $9^{\text {th }}$ edition. 2016; $251-261$

27. Pinar H, Tatevosyants N, Singer D B: Central Nervous System Malformations in a perinatal/neonatal autopsy series: Pediatric and Developmental Pathology. 1998;1:42-48.

28. Laurence K M, Carter C O, David P A: Major central nervous system malformations in south wales- pregnancy factors, seasonal variation, and social class effects, Brit J prev soc Med. 1968;22:212-222.

29. Pujari D K, Pujari A D: Congenital malformations detected at birth - A prospective study in Bangalore: Indian Journal of Public Health Research \& Development. 2012;3(2):28-31.

30. Mahadevan B, Bhat B V: Neural tube defects in Pondicherry: Indian Journal of Paediatrics. 2005 July;72:557-559.

31. Singh A, Sinha S: Risk factors of congenital malformations in North India: A case control study: Journal of Postgraduate Medicine, Education and Research. 2016;50(1):22-27.

How to cite this article: Sarangsa HC, Sarkar JK, Kusre G, Biswas KK. Pattern of malformations in central nervous system and its association with other congenital anomalies in perinates. Ind J Clin Anat Physiol. 2018;5(3):314-319. 